\title{
Respiratory quotient: innovative method for monitoring 'Royal Gala' apple storage in a dynamic controlled atmosphere
}

\author{
Anderson Weber ${ }^{1 *}$, Auri Brackmann², Vanderlei Both², Elizandra Pivotto Pavanello², Rogério de Oliveira Anese ${ }^{2}$, Fabio Rodrigo \\ Thewes $^{2}$
}

${ }^{1}$ Federal University of Southern Frontier- Plant Science Dept. - BR 158, km 7 - 85301-970 - Laranjeiras do Sul, PR - Brazil.

2Federal University of Santa Maria - Plant Science Dept. Postharvest Research Center, Av. Roraima, 1000 - 97105 900 - Santa Maria, RS - Brazil.

*Corresponding author <anderson.weber@uffs.edu.br>

Edited by: Luís Guilherme de Lima Ferreira Guido

Received January 06, 2014

Accepted July 17, 2014

\begin{abstract}
Apples (Malus domestica, Borkh.) which are not stored at low temperature or in a properly controlled atmosphere (CA) may have a high metabolic rate during the postharvest stage resulting in losses in quality. The aim of this study was to evaluate the quality of 'Royal Gala' apple fruit stored in accordance with a new method of dynamic controlled atmosphere (DCA). The respiratory quotient (RQ) was monitored at two temperatures which were then compared using a commercially available technology based on chlorophyll fluorescence DCA (DCA-CF) and static $\mathrm{CA}$. Ethylene production and respiration rates were lower in apples stored in DCA than in $\mathrm{CA}$, as a result of lower 1-aminocyclopropane-1-carboxylate oxidase activity, especially in apples stored in DCA-RQ2. Flesh firmness of apples stored in DCA did not differ from those stored in CA. Apples stored at $1{ }^{\circ} \mathrm{C}$ had less flesh breakdown occurrence and a high percentage of healthy fruit. 'Royal Gala' stored at DCA-RQ2 had less flesh breakdown than apples stored in CA; however, the apples stored in DCA-CF did not differ from those stored in DCA-RQ2 and CA. Apples stored the highest $\mathrm{RQ}$ value $(6$ and 4$)$, especially at $0.5^{\circ} \mathrm{C}$, had low $\mathrm{O}_{2}$ injury occurrence after storage. However the increase in temperature to $1.0^{\circ} \mathrm{C}$, reduced the occurrence of this disorder. Therefore, storage in DCA-RQ2 at $1{ }^{\circ} \mathrm{C}$ or DCA-CF at $0.5^{\circ} \mathrm{C}$ are the recommendations of preference for ensuring maintenance of quality in 'Royal Gala' apples after eight months of storage.

Keywords: ethanol, ethylene, physiological disorders, chlorophyll fluorescence
\end{abstract}

\section{Introduction}

In Brazil, 'Royal Gala' apples (Malus domestica, Borkh.) are stored after harvest under CA conditions with about 1.0 to $1.2 \mathrm{kPa} \mathrm{O}_{2}$ and 2.0 to $2.5 \mathrm{kPa} \mathrm{CO}_{2}$ at a low temperature $\left(0.5\right.$ to $\left.1{ }^{\circ} \mathrm{C}\right)$, and relative humidity of about $94 \%$, for up to seven months (Weber et al., 2011; 2012). If oxygen levels are excessively reduced, hypoxic and even anoxic zones may develop and switch from aerobic respiration to fermentation, which can lead to physiological disorders (Pesis, 2005; Gasser et al., 2010).

A new trend in commercial CA is to consider the use of a dynamic rather than a static controlled atmosphere. In the dynamic controlled atmosphere (DCA), the oxygen level can be changed during the storage period, but remains always slightly above the lowest oxygen limit (LOL). Therefore, the LOL must be measured in real time in the storage rooms. Since 2010, we have been testing a new method to store apples in DCA based on the respiratory quotient (RQ). The $\mathrm{O}_{2}$ partial pressure reduction below the anaerobic compensation point (ACP) triggers an increase in fermentative products and $\mathrm{RQ}$ (Boersig et al., 1988). Therefore, monitoring the RQ will identify the moment when apples reach a critical level of ethanol production, which might damage their tissue (Gasser et al., 2010).

Apples often have higher metabolic activity on the sun-exposed side than on the shaded side (Wright et al., 2012). Therefore, the chlorophyll fluorescence measured on the sun-exposed side of the fruit might result in a higher LOL DCA-CF (Prange et al., 2007). In this way, the LOL might be underestimated if fruit samples are exposed to the shaded side or originate from the inside part of the tree, where it normally has little direct sun exposure.

Temperature is an important factor that affects fruit metabolism and, thus, DCA conditions. Variation of ACP for the same cultivar may occur depending on the storage temperature (Wright et al., 2010). If the storage temperature is higher, LOL increases, resulting in higher $\mathrm{O}_{2}$ partial pressure for storage. The storage temperature generally has a high interaction with the oxygen partial pressure in the storage room $(\mathrm{Chu}, 1999 ;$ Watkins and Liu, 2010; Weber et al., 2011; Kweon et al., 2013).

The objective of this study was to evaluate the quality of 'Royal Gala' apples exposed to the new Respiratory Quotient DCA technology, subject to RQ levels and two temperatures, and compare them with a static controlled atmosphere and the DCA-CF technology.

\section{Materials and Methods}

The experimental material consisted of 'Royal Gala' apples harvested in 2011 from commercial orchards in Vacaria $\left(-28^{\circ} 45^{\prime} \mathrm{S}\right.$ and $\left.-50^{\circ} 88^{\prime} \mathrm{W}\right)$, in the state of Rio Grande do Sul, Brazil. Fruits with any kind of injury or defect were discarded, and then randomized. Treatments were applied in experimental CA chambers with a volume of $233 \mathrm{~L}$ and, finally, the samples were placed in two refrigerated chambers, at $0.5^{\circ} \mathrm{C}( \pm 0.1)$ and $1.0{ }^{\circ} \mathrm{C}( \pm 0.1)$.

The experiment was conducted in a completely randomized design with four replications per treatment. 
Each replication was composed of 30 fruits, resulting in 120 fruits per treatment. The fruits were stored for eight months (Figure 1), in the following conditions: i) Controlled atmosphere $(\mathrm{CA})$ with $1.2 \mathrm{kPa} \mathrm{O}_{2}$ and $2.0 \mathrm{kPa} \mathrm{CO}$; ii) Dynamic controlled atmosphere (DCA) with chlorophyll fluorescence measurement (DCA-CF); iii) DCA with respiratory quotient monitoring at level 2 (DCAQR2); iv) DCA-RQ2 stored at $1{ }^{\circ} \mathrm{C}$; v) DCA-RQ4; vi) DCA-RQ4 stored at $1{ }^{\circ} \mathrm{C}$; and vii) DCA-RQ6. The storage temperature was $0.5^{\circ} \mathrm{C}$, except for treatments iv and vi, and the $\mathrm{CO}_{2}$ partial pressure for all DCA conditions was maintained at $1.2 \mathrm{kPa}$ during the storage period.

Temperature was controlled by thermostats and checked daily by $\mathrm{Hg}$ bulb thermometers (with a 0.1 ${ }^{\circ} \mathrm{C}$ resolution) inserted in the apple flesh, which were stowed in the storage chamber. Relative humidity was monitored by using psychrometers with mercury thermometers in the chambers, and was maintained at 96 $\%+/-2 \%$.

The $\mathrm{O}_{2}$ partial pressure was reduced on the first storage day, about two days after harvest. $\mathrm{O}_{2}$ reduction was obtained by flushing the chamber atmosphere with nitrogen until it reached the pre-established concentration. For DCA conditions, $\mathrm{O}_{2}$ was reduced to $1.7 \mathrm{kPa}$, and the decrease thereafter resulted from the respiration process. $\mathrm{CO}_{2}$ partial pressure was reached by injecting this gas until the desired concentration was reached.

Gas concentration in the chamber was monitored and corrected by a Kronenberger/Siemens ${ }^{\circledR}$ device for automatic control. This equipment corrected $\mathrm{O}_{2}$ partial
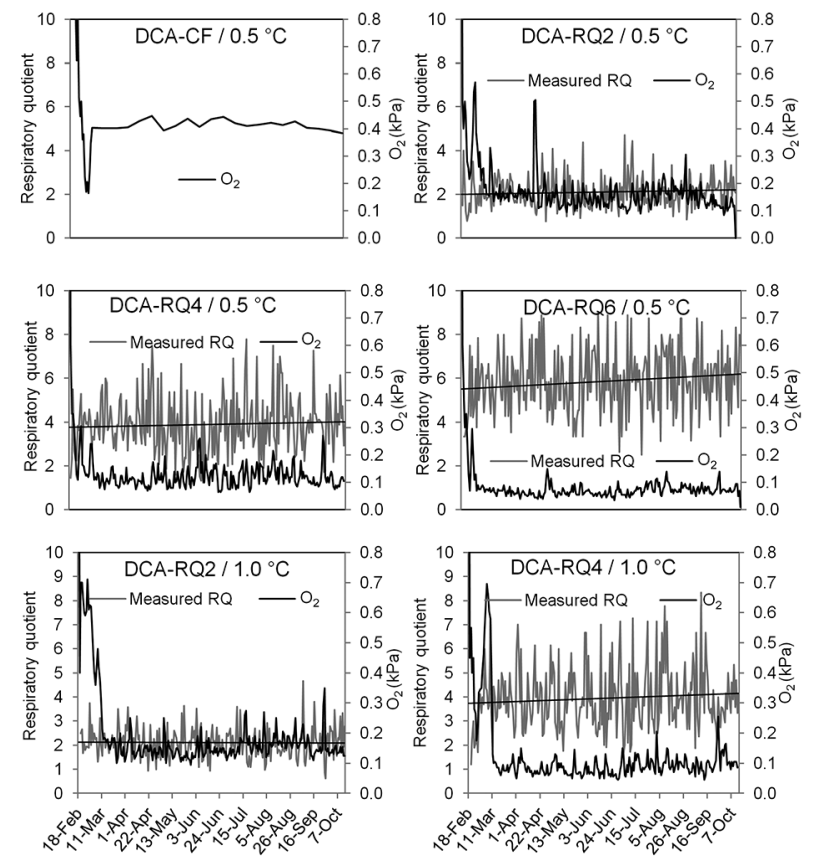

Figure 1 - Oxygen partial pressure $\left(\mathrm{O}_{2}\right)$, respiratory quotient (RQ) variation and RQ trend line during eight months storage of 'Royal Gala' apples in dynamic controlled atmosphere (DCA). pressure by injecting atmospheric air and absorbing the excess of $\mathrm{CO}_{2}$ through air circulation in a $\mathrm{CO}_{2}$ absorber containing hydrated lime until the desired gas concentrations were reached.

The DCA-CF was monitored according to the instructions of Prange et al. (2007). The device was used to monitor chlorophyll fluorescence from six apples during fruit exposure to low $\mathrm{O}_{2}$. Apples cooled to 0.5 ${ }^{\circ} \mathrm{C}$ were placed in a perforated plastic container $(18 \mathrm{~cm}$ width, $27 \mathrm{~cm}$ length, $25 \mathrm{~cm}$ height) with the fluorescence sensors attached to the inside of the container top. The container was placed inside a CA chamber; the chamber was sealed, and covered with black plastic to exclude light. The fluorescence monitoring system was activated and then $\mathrm{O}_{2}$ was subsequently reduced to $1.7 \mathrm{kPa}$ by $\mathrm{N}_{2}$ injection. Afterwards, the respiration process reduced the $\mathrm{O}_{2}$ partial pressure until a change in fluorescence was detected. The lowest $\mathrm{O}_{2}$ set point was determined by identifying the $\mathrm{O}_{2}$ partial pressure where an inflection in the fluorescence signal was detected, and then by increasing $\mathrm{O}_{2}$ by $0.2 \mathrm{kPa}$ as a safety factor (Figure 1). Chlorophyll fluorescence was monitored every hour for the entire storage period during the experiment.

Respiratory Quotient (RQ) DCA conditions were determined daily during the eight months of storage. For RQ determination, $\mathrm{O}_{2}$ and $\mathrm{CO}_{2}$ partial pressure were measured immediately after the chambers were tightly closed. After $24 \mathrm{~h}$, the gas partial pressure was measured again. RQ was calculated as the ratio between the $\mathrm{CO}_{2}$ released and the $\mathrm{O}_{2}$ consumed within a period of $24 \mathrm{~h}$. The $\mathrm{O}_{2}$ partial pressure was controlled by $\mathrm{RQ}$ variations (Figure 1). If the calculated RQ was higher than the preestablished value, $\mathrm{O}_{2}$ was increased to reduce fermentation and reduce $\mathrm{RQ}$. If the calculated RQ was lower than pre-established $R Q$, the $\mathrm{O}_{2}$ partial pressure was decreased to allow increased fermentation.

The quality parameters were evaluated after eight months of storage plus seven days of shelf storage at $20{ }^{\circ} \mathrm{C}$. The parameters were: i) ACC (1-Aminocyclopropane-1-Carboxylate) oxidase enzyme activity determined according to the methodology proposed by Bufler (1986); ii) Ethylene synthesis: determined through the stowage of approximately $1.5 \mathrm{~kg}$ of apples in a $5 \mathrm{~L}$ container which was hermetically sealed for approximately one hour; then, two aliquots from each container were drawn and injected into a gas chromatograph equipped with a flame ionization detector (FID) and a 2.0 m Porapak N80/100 steel column; iii) Respiratory rate: determined through air circulation, from the same ethylene synthesis analysis container, using a gas analyzer, with an infrared gas analyzer (IRGA) system which analyzed $\mathrm{CO}_{2}$ partial pressure in the container; iv) Flesh firmness: determined with the aid of a penetrometer equipped with an $11 \mathrm{~mm}$ probe; v) Flesh breakdown; vi) Mealiness; vii) Low $\mathrm{O}_{2}$ injury: determined by counting the apples that demonstrated such disorder; viii) Healthy fruit: determined by counting the apples which did not present any kind of physi- 
ological disorders or incidence of decay; ix) Titratable acidity: determined by titration with $0.1 \mathrm{~N} \mathrm{NaOH}$ of a solution with $10 \mathrm{~mL}$ of juice diluted in $100 \mathrm{~mL}$ distilled water, until $\mathrm{pH} 8.1$ was reached; and x) Soluble solids: determined by refractometry.

Analysis of variance (ANOVA) was performed for all evaluated parameters. ANOVA significant parameters were compared through Tukey's test at 0.05. Data were tested for normality and homogeneity of errors by the Lilliefor and Bartlett tests, respectively. The data expressed in percentage were transformed by the formula arc.sen $((\mathrm{x}+0.5) / 100)^{0.5}$ before analysis of variance; however, the averages shown in this paper have been back-transformed. The software programs, Sisvar and Action for Excel, were used to run the statistical analysis.

\section{Results and Discussion}

Ethylene production was reduced by the dynamic controlled atmosphere with respiratory quotient 4 and 6 at $0.5^{\circ} \mathrm{C}$ after $1 / 2$ day of shelf storage. However, after 2 and 4 days of shelf storage, all DCA conditions reduced ethylene production. The temperature increase from 0.5 ${ }^{\circ} \mathrm{C}$ to $1.0^{\circ} \mathrm{C}$ just resulted in higher ethylene production for DCA-RQ4 at 1/2 day of shelf storage, having no effect on ACC oxidase activity and on ethylene production during shelf storage (Table 1). The reduced oxygen level in the storage room reduces oxidative metabolism by enhancing fermentative pathways, which induces ethanol production (Imahori et al., 2013). Therefore, ripening may be delayed by the induced production of ethanol metabolites or ethanol application (Asoda et al., 2009), especially by decreasing ACC oxidase activity and ethylene production (Liu et al., 2012). Brackmann et al. (2013) also observed lower ACC oxidase activity in 'Royal Gala' apples when stored under low oxygen partial pressure $(0.6 \mathrm{kPa})$. The highest ethylene production was measured at the first evaluation, that is, after $1 / 2$ day at shelf storage. After 2 days until 6 days at $20^{\circ} \mathrm{C}$, the ethylene production was lower than the first evaluation, however, this pattern was not observed for the DCA-RQ4 and DCA-RQ6 stored at $0.5{ }^{\circ} \mathrm{C}$ (Table 1), while the respiration onset at DCA-RQ2 and DCA-RQ4 occurred on the second day of shelf storage (Table 2).

The respiration rate was higher for $\mathrm{CA}$ storage than for DCA-RQ2 even at 0.5 or $1.0{ }^{\circ} \mathrm{C}$. 'Royal Gala' apples stored at DCA-RQ4 and DCA-RQ6 did not differ from CA storage during shelf storage (Table 2). The respiration rate is normally closely associated with the ethylene production rate, especially when the oxygen level in the storage room is very low. If their rate is low, the entire metabolism is reduced and fruit quality is maintained (Thompson, 2010). However, flesh firmness was not related to respiration rate and ethylene production during shelf storage. Flesh firmness was lowest for apples stored at $1{ }^{\circ} \mathrm{C}$ among all samples, differing only from DCA-RQ6 (Table 3).

Fruit firmness is the dominant factor in consumer acceptance of apples, but sugar content and acid content also play a role in defining quality for specific cultivars (Harker et al., 2008). In this experiment, flesh firmness of apples stored in DCA did not differ from those stored in $\mathrm{CA}$; however, some flesh softening occurred in all treatments 6 to $13 \mathrm{~N}$, which is the difference between the initial flesh firmness and that after the storage period) after eight months of storage (Table 3). Flesh softening in apples occurs through the activation of cell wall degrading enzymes, such as polygalacturonase, pectatelyase, pectin methylesterase, endoglucanase, $\beta$-xylosidase, and especially $\beta$-galactosidase, which are activated by ethylene (Wei et al., 2010; Ortiz, 2011). In addition to higher ethylene biosynthesis for apples stored at CA during the first four days at $20{ }^{\circ} \mathrm{C}$, the entire ethylene production was low. Therefore, the total amount of ethylene produced may not have been enough to activate cell wall degrading enzymes, and, therefore, did not affect fruit firmness (Table 3).

Table 1 - Ethylene production rate and 1-Aminocyclopropane-1-Carboxylate (ACC) oxidase activity of 'Royal Gala' apples after eight months of storage at different temperatures and dynamic controlled atmosphere (DCA) conditions plus seven days of shelf storage at $20^{\circ} \mathrm{C}$.

\begin{tabular}{|c|c|c|c|c|c|c|}
\hline \multirow{3}{*}{ DCA conditions } & \multirow{3}{*}{ Temperature } & \multicolumn{4}{|c|}{ Ethylene production rate } & \multirow{3}{*}{ ACC oxidase } \\
\hline & & \multicolumn{4}{|c|}{ Days at $20^{\circ} \mathrm{C}$} & \\
\hline & & $1 / 2$ day & 2 days & 4 days & 6 days & \\
\hline & ${ }^{\circ} \mathrm{C}$ & \multirow{2}{*}{\multicolumn{4}{|c|}{$\begin{array}{c}\mu \mathrm{L} \mathrm{C}_{2} \mathrm{H}_{4} \mathrm{~kg}^{-1} \mathrm{~h}^{-1} \longrightarrow \\
0.39\end{array}$}} & $\eta \mathrm{L} \mathrm{C} \mathrm{C}_{2} \mathrm{H}_{4} \mathrm{~g}^{-1} \mathrm{~h}^{-1}$ \\
\hline \multicolumn{2}{|c|}{ Initial Analysis** } & & & & & 18.9 \\
\hline$C A^{* * *}$ & 0.5 & \multicolumn{4}{|l|}{$0.18 \mathrm{aA}^{*}$} & 60.19 a \\
\hline DCA-CF & 0.5 & $0.08 \mathrm{bcA}$ & $0.00 \mathrm{bB}$ & $0.01 \mathrm{bB}$ & $0.01 \mathrm{aB}$ & $39.00 \mathrm{~b}$ \\
\hline DCA-RQ2 & 0.5 & $0.12 a b A$ & $0.01 \mathrm{bB}$ & $0.01 \mathrm{bB}$ & $0.03 \mathrm{aB}$ & $14.38 \mathrm{c}$ \\
\hline DCA-RQ2 & 1.0 & $0.09 \mathrm{bcA}$ & 0.03 bB & $0.02 \mathrm{bB}$ & $0.03 \mathrm{aB}$ & $18.96 \mathrm{c}$ \\
\hline DCA-RQ4 & 0.5 & $0.05 \mathrm{cdA}$ & $0.02 \mathrm{bA}$ & $0.03 \mathrm{bA}$ & $0.02 \mathrm{aA}$ & $15.05 \mathrm{c}$ \\
\hline DCA- RQ4 & 1.0 & $0.14 a b A$ & $0.02 \mathrm{bB}$ & $0.02 \mathrm{bB}$ & $0.01 \mathrm{aB}$ & $25.47 \mathrm{c}$ \\
\hline DCA-RQ6 & 0.5 & $0.02 \mathrm{dA}$ & $0.00 \mathrm{bA}$ & $0.02 \mathrm{bA}$ & $0.01 \mathrm{aA}$ & $38.48 b$ \\
\hline \multicolumn{2}{|l|}{ CV (\%) } & \multicolumn{4}{|c|}{66.94} & 16.82 \\
\hline
\end{tabular}

${ }^{*}$ Means followed by equal letters, lowercase in the columns and uppercase in the lines, do not differ (Tukey's test, $\mathrm{p}<0.05$ ); ${ }^{*}$ Initial analysis took place before fruit storage; ${ }^{* *} \mathrm{CA}$ (controlled atmosphere) was $1.2 \mathrm{kPa} \mathrm{O} / 2.0 \mathrm{kPa} \mathrm{CO}_{2} ; \mathrm{CO}_{2}$ for DCA was $1.2 \mathrm{kPa}$; CF: chlorophyll fluorescence; RQ: respiratory quotient; $\mathrm{VC}$ : Coefficient of Variation. 
Table 2 - Respiration rate of 'Royal Gala' apples after eight months at different temperature and dynamic controlled atmosphere (DCA) conditions, plus seven days of shelf storage at $20^{\circ} \mathrm{C}$.

\begin{tabular}{|c|c|c|c|c|c|}
\hline \multirow{3}{*}{ DCA conditions } & \multirow{3}{*}{ Temperature } & \multicolumn{4}{|c|}{ Respiration rate } \\
\hline & & \multicolumn{4}{|c|}{ Days at $20^{\circ} \mathrm{C}$} \\
\hline & & $1 / 2$ day & 2 days & 4 days & 6 days \\
\hline \multirow{2}{*}{\multicolumn{2}{|c|}{ Initial Analysis ${ }^{* *}{ }^{\circ} \mathrm{C}$}} & \multirow{2}{*}{\multicolumn{4}{|c|}{5.89}} \\
\hline & & & & & \\
\hline$C A^{* * *}$ & 0.5 & $4.48 \mathrm{aA}^{*}$ & $4.56 \mathrm{aA}$ & $3.41 \mathrm{aB}$ & $3.30 \mathrm{aB}$ \\
\hline DCA-CF & 0.5 & $3.79 \mathrm{abA}$ & $3.38 \mathrm{bcAB}$ & $2.56 \mathrm{bC}$ & $2.94 \mathrm{abBC}$ \\
\hline DCA- RQ2 & 0.5 & $2.47 \mathrm{~dB}$ & $3.24 \mathrm{cA}$ & $2.50 \mathrm{bAB}$ & $2.34 \mathrm{bB}$ \\
\hline DCA-RQ2 & 1.0 & $2.78 \mathrm{cdB}$ & $3.60 \mathrm{bcA}$ & $2.50 \mathrm{bB}$ & $2.58 \mathrm{bB}$ \\
\hline DCA-RQ4 & 0.5 & $3.31 \mathrm{bcA}$ & $3.75 \mathrm{abcA}$ & $3.14 \mathrm{abA}$ & $3.22 \mathrm{aA}$ \\
\hline DCA-RQ4 & 1.0 & $3.11 \mathrm{bcdB}$ & $3.87 \mathrm{abcA}$ & $3.10 \mathrm{abB}$ & $2.65 \mathrm{abB}$ \\
\hline DCA-RQ6 & 0.5 & $3.49 \mathrm{bcAB}$ & $4.17 \mathrm{abA}$ & $2.98 \mathrm{abB}$ & $3.25 \mathrm{aB}$ \\
\hline \multicolumn{2}{|c|}{ VC (\%) } & \multicolumn{4}{|c|}{11.60} \\
\hline
\end{tabular}

* Means followed by equal letters, lowercase in the columns and uppercase in the lines, do not differ by Tukey's test, at $5 \%$ probability; * ${ }^{*}$ Initial analysis took place before fruit storage; ${ }^{\star \star \star}{ }^{*} \mathrm{CA}$ (controlled atmosphere) was $1.2 \mathrm{kPa} \mathrm{O} / 2.0 \mathrm{kPa} \mathrm{CO}{ }_{2} ; \mathrm{CO}_{2}$ for DCA was $1.2 \mathrm{kPa}$; CF: chlorophyll fluorescence; RQ: respiratory quotient; VC: Variation Coefficient.

Table 3 - Flesh firmness, titratable acidity and soluble solids of 'Royal Gala' apples after eight months of storage at different temperature and dynamic controlled atmosphere (DCA) conditions, plus seven days of shelf storage at $20^{\circ} \mathrm{C}$.

\begin{tabular}{|c|c|c|c|c|}
\hline DCA conditions & Temperature & Flesh firmness & Titratable acidity & Soluble solids \\
\hline & ${ }^{\circ} \mathrm{C}$ & $\mathrm{N}$ & $\%$ Malic Acid & ${ }^{\circ}$ Brix \\
\hline \multicolumn{2}{|c|}{ Initial Analysis* * } & 76.4 & 0.292 & 11.2 \\
\hline$C A^{* * *}$ & 0.5 & $66.9 a b^{*}$ & $0.237 c$ & $12.0 \mathrm{ab}$ \\
\hline DCA-CF & 0.5 & $68.8 a b$ & $0.237 c$ & $12.1 \mathrm{a}$ \\
\hline DCA- RQ2 & 0.5 & $66.9 \mathrm{ab}$ & $0.245 a b$ & $12.0 \mathrm{ab}$ \\
\hline DCA- RQ2 & 1.0 & $63.7 \mathrm{~b}$ & $0.265 a$ & $11.9 \mathrm{abc}$ \\
\hline DCA- RQ4 & 0.5 & $67.0 \mathrm{ab}$ & $0.241 a b$ & $11.7 \mathrm{~cd}$ \\
\hline DCA- RQ4 & 1.0 & $63.1 b$ & $0.258 a b$ & $11.8 \mathrm{bcd}$ \\
\hline DCA-RQ6 & 0.5 & $70.2 \mathrm{a}$ & $0.253 a b c$ & $11.5 \mathrm{~d}$ \\
\hline \multicolumn{2}{|c|}{ VC (\%) } & 4.17 & 2.97 & 1.42 \\
\hline
\end{tabular}

Although DCA did not maintain higher flesh firmness of the apples stored in RQ 2 and 4, it kept the titratable acidity higher after seven days of shelf storage. This result is in accordance with the lower respiration rate mainly just after $1 / 2$ day at shelf storage (Table 2). However, with higher RQ, which means lower oxygen level in the storage chamber, lower soluble solids were measured (Table 3). Hypoxic concentration in a storage room results in an induction of the fermentative metabolic processes in order to supply cells with energy. However, the energy yield on anaerobic respiration is very low, with only two ATPs produced per glucose molecule (Raymond et al., 1985). Therefore, for cells to maintain energy supply and cell function, e.g., selective membrane permeability and basic metabolism, a greater amount of glucose must enter glycolysis, which in turn, leads to a decrease in soluble solids and also an increase in ethanol accumulation that might culminate in higher physiological disorders (Franck et al., 2007).

Apples stored at $1{ }^{\circ} \mathrm{C}$ had lower occurrence of flesh breakdown and higher percentage of healthy fruit
(Table 4). Weber et al. (2011) also observed lower occurrence of physiological disorders for 'Royal Gala' apples stored in $\mathrm{CA}$ at $1{ }^{\circ} \mathrm{C}$ than those stored at 0.5 or $0.0^{\circ} \mathrm{C}$. The $72 \%$ of healthy fruits obtained in the best storage condition was not high; this percentage could be seen as commercially unviable. However, all fruits with any kind of inner physiological disorder in this study, regardless of its size, were considered not healthy. For commercial store companies, the inner quality is not a factor that excludes apples from the market.

Flesh breakdown is often associated with deficient gas diffusion, which can cause anoxic spots in fruit flesh, resulting in the occurrence of this disorder (Franck et al., 2007). However, temperature normally does not influence tissue diffusion (Schotsmans et al., 2003; Ho et al., 2006). Therefore, the main reason for the higher occurrence of flesh breakdown at $0.5{ }^{\circ} \mathrm{C}$ was probably chilling injury. Diffuse flesh browning in 'Pink Lady ${ }^{\mathrm{TM}}$ apples is characterized by browning throughout the cortex tissue of the fruit, with the vascular tissue remaining clear and relatively unaffected (James and Jobling, 2008). 
Table 4 -Flesh breakdown, mealiness, low $\mathrm{O}_{2}$ injury, and healthy fruit percentages of 'Royal Gala' apples after eight months of storage at different temperature and dynamic controlled atmosphere (DCA) conditions, plus seven days of shelf storage at $20^{\circ} \mathrm{C}$.

\begin{tabular}{lccccc}
\hline DCA conditions & Temperature & Flesh breakdown & Mealiness & Low $\mathrm{O}_{2}$ injury & Healthy fruit \\
\cline { 2 - 5 } CA $^{* *}$ & ${ }^{\circ} \mathrm{C}$ & $22 \mathrm{a}^{*}$ & $39 \mathrm{a}$ & $0 \mathrm{c}$ & $57 \mathrm{c}$ \\
\cline { 2 - 2 } & 0.5 & $19 \mathrm{ab}$ & $35 \mathrm{ab}$ & $0 \mathrm{c}$ & $66 \mathrm{ab}$ \\
DCA- RQ2 & 0.5 & $15 \mathrm{~b}$ & $30 \mathrm{ab}$ & $1 \mathrm{c}$ & $66 \mathrm{ab}$ \\
DCA- RQ2 & 0.5 & $8 \mathrm{c}$ & $29 \mathrm{ab}$ & $0 \mathrm{c}$ & $69 \mathrm{ab}$ \\
DCA- RQ4 & 1.0 & $18 \mathrm{ab}$ & $34 \mathrm{ab}$ & $8 \mathrm{~b}$ & $50 \mathrm{~cd}$ \\
DCA- RQ4 & 0.5 & $8 \mathrm{c}$ & $23 \mathrm{~b}$ & $1 \mathrm{c}$ & $72 \mathrm{a}$ \\
DCA- RQ6 & 1.0 & $18 \mathrm{ab}$ & $23 \mathrm{~b}$ & $49 \mathrm{a}$ & $43 \mathrm{~d}$ \\
VC (\%) & 0.5 & 6.77 & 9.96 & 27.05 & 6.03
\end{tabular}

DCA was 1.2 kPa; CF: chlorophyll fluorescence; RQ: respiratory quotient; V.C.: Variation Coefficient.

'Royal Gala' apples stored at DCA-RQ2 (at 0.5 or $1.0^{\circ} \mathrm{C}$ ) and those stored in DCA-RQ4 at $1{ }^{\circ} \mathrm{C}$ had lower flesh breakdown than those stored in $\mathrm{CA}$; however, the apples stored in DCA-CF did not differ from those stored in CA (Table 4). Watkins (2008) showed that DCA was especially effective to reduce superficial scald development in 'Cortland' and 'Delicious' apples, but they did not mention flesh breakdown. LOL is inherently variable, like fruit mass, color, sugar or acid levels, even among apples from a given cultivar and tree or between the sunexposed and shaded regions of a single fruit (Wright et al., 2012). Therefore, the current DCA-CF recommendations suggest that $\mathrm{O}_{2}$ partial pressure should be set at 0.2-0.3 $\mathrm{kPa}$ above LOL (Prange et al., 2007). If the $\mathrm{O}_{2}$ partial pressure set above LOL, fruit quality might be not maintained at its best. As a result, apples stored in DCA-CF might not differ from those stored in CA condition.

Mealiness was higher in apples stored at CA condition; however, it differs only for apples stored at DCARQ4 plus $1{ }^{\circ} \mathrm{C}$ and DCA-RQ6 (Table 4). Mealiness is a physiological disorder which is characterized by the sensation of a deteriorative texture and lack of juiciness that degrades the quality of apples and makes them unsuitable for marketing. The intensity of juiciness decreased while the intensity of mealiness increased, and these changes were associated with the deterioration of the mechanical strength of the apple tissue during storage (Billy et al., 2008). The most relevant biochemical marker which is associated with texture change, as a mean of mealiness appearance, is the increase of galacturonic acid content analyzed in water soluble pectin extracts (Billy et al., 2008).

The apples stored at higher RQ (6 and 4), especially at $0.5{ }^{\circ} \mathrm{C}$, showed skin browning after storage, probably because of the low oxygen level during storage (Table 4). The temperature increase to $1.0{ }^{\circ} \mathrm{C}$ reduced the occurrence of this disorder. The apples from DCARQ4, at any temperature, and DCA-RQ6 had an alcoholic taste after eight months of storage and even after seven days of shelf storage (data not shown). Therefore, skin injury probably occurs because of higher fermentation under high RQ conditions, which results in a larger amount of ethanol, acetaldehyde and ethyl acetate production which, in turn, can damage apple skin (Pesis, 2005). The disorder caused by low $\mathrm{O}_{2}$, and in addition to higher flesh breakdown, reduced the percentage of healthy apples stored at $0.5{ }^{\circ} \mathrm{C}$ in the DCA-RQ4 and DCA-RQ6 treatments (Table 4).

\section{Conclusions}

'Royal Gala' apples stored in DCA-RQ2 at $0.5^{\circ} \mathrm{C}$ maintain fruit quality comparable as those stored in DCA-CF and better than those stored in static CA after eight months of storage. Apples stored in DCA-RQ4 at 1 ${ }^{\circ} \mathrm{C}$ also maintain fruit quality. The lower $\mathrm{O}_{2}$ partial pressure inside the storage chamber can result in higher fermentation disorder risk. Therefore, DCA-RQ2 is recommended. A temperature increase from $0.5^{\circ} \mathrm{C}$ to $1.0^{\circ} \mathrm{C}$ reduces the incidence of physiological disorders, such as low $\mathrm{O}_{2}$ injury and flesh breakdown in 'Royal Gala' apples stored in DCA-RQ.

\section{Acknowledgements}

To the National Council for Scientific and Technological Development (CNPq), the Coordination for the Improvement of Higher Education Personnel (CAPES) and the Research Support Foundation of the State of Rio Grande do Sul (FAPERGS), for their financial support.

\section{References}

Asoda, T.H.; Kato, M.; Suzuki, Y. 2009. Effects of postharvest ethanol vapor treatment on ethylene responsiveness in broccoli. Postharvest Biology and Technology 52: 216-220.

Billy, L.; Mehinagic, E.; Royer, G.; Renard, C.M.G.C.; Arvisenet, G.; Prost, C.; Jourjon, F. 2008. Relationship between texture and pectin composition of two apple cultivars during storage. Postharvest Biology and Technology 47: 315-324.

Boersig, M.R.; Kader, A.A.; Romani, R.J. 1988. Aerobic-anerobic respiratory transition in pear fruit and cultured pear fruit cells. Journal of the American Society for Horticultural Science 113: 869-873. 
Brackmann, A.; Anese, R.O.; Weber, A.; Both, V.;Gasperin, A.R.;Pavanello, E.P. 2013. Effect of initial low oxygen stress combined with 1-methylcyclopropene in 'Royal Gala' apple quality stored under ultralow $\mathrm{O}_{2}$. Semina: Ciências Agrárias 34: 1185-1194 (in Portuguese, with abstract in English).

Bufler, G. 1986. Ethylene-promoted conversion of 1-aminocyclopropene-1-carboxylic acid to ethylene in peel of apple at various stages of fruit development. Plant Physiology 80: 539-543.

Chu, C.L. 1999. Effects of storage temperature, storage atmosphere, and growing region on internal browning disorder of 'McIntosh' apples. HortTechnology9: 75-78.

Franck, C.; Lammertyn, J.; Ho, Q.T.; Verboven, P.; Verlinden, B.; Nicolaï, B.M. 2007. Browning disorders in pear fruit. Postharvest Biology and Technology 43: 1-13.

Gasser, F.; Eppler, T.; Naunheim, W.; Gabioud, S.; Nising, A.B. 2010. Dynamic CA storage of apples: monitoring of the critical oxygen concentration and adjustment of optimum conditions during oxygen reduction. Acta Horticulturae 796: 69-76.

Harker, F.R.; Kupferman, E.M.; Marin, A.; Gunson, F.A.B.;Triggs, C.M. 2008. Eating quality standards for apples based on consumer preferences. Postharvest Biology and Technology 50: 70-78.

Ho, Q.T.; Verlinden, B.E.; Verboven, P.; Nicolaï, B.M. 2006. Gas diffusion properties at different positions in the pear. Postharvest Biology and Technology 41: 113-120.

Imahori, Y.; Yamamoto, K.; Tanaka, H.; Bai, J. 2013. Residual effects of low oxygen storage of mature green fruit on ripening processes and ester biosynthesis during ripening in bananas. Postharvest Biology and Technology 77: 19-27.

Kweon, H.J.; Kang, I.K.; Kim, M.J.; Lee, J.; Moon, Y.S.; Choi, C.; Choi, D.G.; Watkins, C.B. 2013. Fruit maturity, controlled atmosphere delays and storage temperature affect fruit quality and incidence of storage disorders of 'Fuji' apples. Scientia Horticulturae 157: 60-64.

Liu, W.W.; Qi, H.Y.; Xu, B.H.; Li, Y.; Tian, X.B.; Jiang, Y.Y.; Xu, X.F.;Lv, D.Q. 2012. Ethanol treatment inhibits internal ethylene concentrations and enhances ethyl ester production during storage of oriental sweet melons (Cucumis melo var. makuwa Makino). Postharvest Biology and Technology 67: 75-83.

Ortiz, A.; Graell, Jordi.; Lara, I. 2011. Cell wall-modifying enzymes and firmness loss in ripening 'Golden Reinders' apples: a comparison between calcium dips and ULO storage. Food Chemistry 128: 1072-1079.

Pesis, E. 2005. The role of the anaerobic metabolites, acetaldehyde and ethanol, in fruit ripening, enhancement of fruit quality and fruit deterioration. Postharvest Biology and Technology 37: 1-19.
Prange, R.K.; Delong, J.M.; Harrison, P.; Mclean, S.;Scrutton, J.; Cullen, J. 2007. Method and apparatus for monitoring a condition in chlorophyll containing matter. U.S. Patent, n.WO/2002/006795.

Raymond, P.; Al-Ani, A.; Pradet, A. 1985. ATP production by respiration and fermentation, and energy charge during aerobiosis and anaerobiosis in twelve fatty and starchy germinating seeds. Plant Physiology 79: 879-884.

Schotsmans, W.; Verlinden, B.E.; Lammertyn, J.; Nicolaï, B.M. 2003. Simultaneous measurement of oxygen and carbon dioxide diffusivity in pear fruit tissue. Postharvest Biology and Technology 29: 155-166.

Thompson, A.K. 2010. Controlled Atmosphere Storage of Fruits and Vegetables. 2ed. CAB International, Wallingford, UK.

Watkins, C.B. 2008. Dynamic controlled atmosphere storage: a new technology for the New York storage industry? New York Fruit Quarterly 16: 23-26.

Watkins, C.B.; Liu, F.W. 2010. Temperature and carbon dioxide interactions on quality of controlled atmosphere-stored 'Empire' apples. Hortscience 45: 1708-1712.

Weber, A.; Brackmann, A.; Anese, R.O.; Both, V.; Pavanello, E.P. 2011. 'Royal Gala' apple quality stored under ultralow oxygen concentration and low temperature conditions. Pesquisa Agropecuária Brasileira 46: 1597-1602.

Weber, A.; Brackmann, A.; Thewes, F.R.; Both, V.; Anese, R.O.; Schorr, M.R.W. 2012. Relative humidity and its interaction with the storage temperature of 'Gala' apples and mutants. Ciência Rural 42: 2159-2165.

Wei, J.; Ma, F.; Shi, S.; Qi, X.; Zhu, X.; Yuan, J. 2010. Changes and postharvest regulation of activity and gene expression of enzymes related to cell wall degradation in ripening apple fruit. Postharvest Biology and Technology 56: 147-154.

Wright, A.H.; DeLong, J.M.; Harrison, P.A.; Gunawardena, A.H.L.A.N.; Prange, R.K. 2010. The effect of temperature and other factors on chlorophyll a fluorescence and the lower oxygen limit in apples (Malus domestica). Postharvest Biology and Technology 55: 21-28.

Wright, A.H.; DeLong, J.M.; Gunawardena, A.H.L.A.N.; Prange, R.K. 2012. Dynamic controlled atmosphere (DCA): does fluorescence reflect physiology in storage? Postharvest Biology and Technology 64: 19-30. 